\title{
Antioxidant capacity and concentration of redox-active trace mineral in fully weaned intra-uterine growth retardation piglets
}

\author{
Hao Zhang, Yue Li and Tian Wang*
}

\begin{abstract}
Background: The redox status of intra-uterine growth retardation (IUGR) piglets post-weaning has been poorly studied. Methods: Newborns from twenty-four sows were weighted, weaned at $21 \mathrm{~d}$ and fed a starter diet until sampling. Sampling was done at $14 \mathrm{~d}$ post-weaning. A piglet was defined as IUGR when its birth weight was 2 SD below the mean birth weight of the total population. At weaning, eighteen piglets with nearly equal body weight from each category (i.e. IUGR or normal birth weight (NBW) piglets) were selected and then allocated to two treatments, consisted of six replicates with each pen having three piglets.

Results: Compared with NBW group, IUGR significantly decreased average daily gain $(P<0.001)$, average daily feed intake $(P=0.003)$, and feed efficiency $(P<0.001)$ of piglets during the first two weeks post-weaning. IUGR decreased the activities of total antioxidant capacity $(P=0.019)$, total superoxide dismutase (T-SOD, $P=0.023)$, and ceruloplasmin $(P=0.044)$ but increased the levels of malondialdehyde $(P=0.040)$ and protein carbonyl $(P=0.010)$ in plasma. Similarly, the decreased activities of T-SOD $(P=0.005)$, copper- and zinc-containing superoxide dismutase $(\mathrm{Cu} / \mathrm{Zn}-\mathrm{SOD}, P=0.002)$, and catalase $(P=0.049)$ was observed in the liver of IUGR piglets than these of NBW piglets. IUGR decreased hepatic Cu/Zn-SOD activity $(P=0.023)$ per unit of $\mathrm{Cu} / \mathrm{Zn}-\mathrm{SOD}$ protein in piglets when compared with NBW piglets. In addition, IUGR piglets exhibited the decreases in accumulation of copper in both plasma $(P=0.001)$ and liver $(P=0.014)$, as well as the concentrations of iron $(P=0.002)$ and zinc $(P=0.048)$ in liver. Compared with NBW, IUGR down-regulated mRNA expression of Cu/Zn-SOD $(P=0.021)$ in the liver of piglets.

Conclusions: The results indicated that IUGR impaired antioxidant capacity and resulted in oxidative damage in fully weaned piglets, which might be associated with the decreased levels of redox-active trace minerals. This study highlights the importance of redox status in IUGR offspring and provides a rationale for alleviating oxidative damage by dietary interventions aiming to supplement trace minerals and to restore redox balance in the future.
\end{abstract}

Keywords: Antioxidant capacity, Intra-uterine growth retardation, Oxidative damage, Piglet, Redox-active trace mineral

\section{Background}

Malnutrition, environmental stress, hypoxia or any other reasons during pregnancy may lead to growth lag and developmental restriction of the fetus, this condition is termed "intra-uterine growth retardation" (IUGR) [1]. Approximately 5-10 \% of human fetuses worldwide suffer from IUGR and IUGR fetus has a reduced functional capacity and fewer cells [2]. The latter may be part

\footnotetext{
* Correspondence: tianwangnjau@163.com

College of Animal Science and Technology, Nanjing Agricultural University, Weigang 1, Nanjing 210095, China
}

(c) 2015 Zhang et al. Open Access This article is distributed under the terms of the Creative Commons Attribution 4.0 International License (http://creativecommons.org/licenses/by/4.0/, which permits unrestricted use, distribution, and reproduction in any medium, provided you give appropriate credit to the original author(s) and the source, provide a link to the Creative Commons license, and indicate if changes were made. The Creative Commons Public Domain Dedication waiver (http://creativecommons.org/publicdomain/zero/1.0/) applies to the data made available in this article, unless otherwise stated. trade-off in the development of tissues that are less critical to the body, such as liver, pancreas and intestine [3-5]. Therefore, IUGR exerts a permanent stunting effect on postnatal growth and impairs long-term health in offspring [1].

The pig has been recognized as one of the ideal models for the study of clinic nutrition in humans because of its similar metabolic features, cardiovascular systems, and proportional organ sizes [6]. An increasing number of studies have emerged in recent years to 
investigate the metabolic changes in IUGR pigs and some novel mechanistic insights have been obtained [5, 7], but few studies have focused on the effect of IUGR on accumulation of trace minerals. Trace minerals play important roles in multiple biological processes and the alteration of local and systemic trace minerals often occurs under chronic inflammation or oxidative stress [8]. Substantial evidence suggests that redox-active trace minerals, such as selenium $(\mathrm{Se})$, iron $(\mathrm{Fe})$, copper $(\mathrm{Cu})$, zinc $(\mathrm{Zn})$ and manganese $(\mathrm{Mn})$, are important modulators of cellular redox status and oxidative stress $[8,9]$. However, the levels of these minerals and their alterations in IUGR offspring have not been studied at systems biology levels, especially during the early period post-weaning when the piglet is subjected to several stressors. Therefore, the aim of the present study was to investigate the effects of IUGR on redox status and levels of redox-active trace minerals in fully weaned piglets in order to provide a rationale for establishing new feeding strategies of IUGR offspring.

\section{Materials and methods}

Experimental design, diets and management

Experimental protocols were permitted by the Institutional Animal Care and Use Committee of Nanjing Agricultural University (NJAU-CAST-2014-179).

Twenty-four pregnant sows (Landrace $\times$ Yorkshire) with similar parity (second or third) were given a commercial diet during pregnancy. At birth, birth weight and sex of each newborn piglet (Duroc $\times$ (Landrace $\times$ Yorkshire) $)$ were recorded. A piglet was defined as IUGR when its birth weight was 2 SD below the mean birth weight of the total population [10]. In each litter, one male IUGR piglet with birth weight of $0.95 \pm 0.04 \mathrm{~kg}$ and one normal samesex littermates with birth weight of $1.58 \pm 0.04 \mathrm{~kg}$ were chosen. At weaning ( $21 \mathrm{~d}$ of age), eighteen piglets with nearly equal body weight from each category (i.e. IUGR or normal birth weight (NBW) piglets) were selected and subsequently transferred to the weaner unit for experiment. Piglets were then allocated to two treatments, consisted of six pen replicates with each pen having three piglets. Both IUGR and NBW piglets were fed a commercial diet for $14 \mathrm{~d}$. The composition and nutrition level of the diet was given in Table 1, which was formulated according to the National Research Council (2012) to meet the nutrient requirements of the piglets [11]. Piglets had free access to food and water until the day of sampling.

\section{Sample collection}

At $35 \mathrm{~d}$ of age, six piglets with nearly equal body weight from each treatment (one piglet per pen) were selected. Heparinized blood samples were drawn by jugular vein puncture, and then centrifuged at 2,000 $\mathrm{g}$ for $10 \mathrm{~min}$ at $4{ }^{\circ} \mathrm{C}$. The acquired plasma was stored at $-80{ }^{\circ} \mathrm{C}$ for further determination. All piglets were killed by electrical stunning and exsanguination, the liver was then rapidly removed. Liver samples were collected from the left lateral lobe within $5 \mathrm{~min}$, which were rapidly frozen in liquid nitrogen and stored at $-80{ }^{\circ} \mathrm{C}$ for further analyses.

\section{Growth performance measurement}

Pig body weight and feed intake were recorded and measured on a pen basis at weaning and sampling to calculate average daily gain (ADG), average daily feed intake (ADFI), and feed efficiency (FE).

\section{Antioxidant capacity measurement}

The activities of total superoxide dismutase (T-SOD), copper- and zinc-containing superoxide dismutase $(\mathrm{Cu} /$ Zn-SOD), glutathione peroxidase (GPX), total antioxidant capacity (T-AOC) and ceruloplasmin (CP), and the concentrations of malondialdehyde (MDA) and protein carbonyl in the plasma, the activities of T-AOC, T-SOD, $\mathrm{Cu} / \mathrm{Zn}$-SOD, GPX and catalase (CAT), and concentrations of MDA, protein carbonyl and total protein in the liver were determined using colorimetric methods with spectrophotometer, respectively. The assay kits used in the assay was purchased from the Nanjing Jiancheng Institute of Bioengineering (Nanjing, Jiangsu, China) and the assay was conducted following the instructions of the kits. The results in the liver were normalised against total protein concentration in each sample for intersample comparison.

Briefly, the activities of T-SOD and $\mathrm{Cu} / \mathrm{Zn}$-SOD were assayed at $550 \mathrm{~nm}$ by use of the nitrite method as described by Ōyanagui [12], $\mathrm{Cu} / \mathrm{Zn}$-SOD activity was determined on the chloroform/ethanol (3:5, v/v) extract. One unit of T-SOD or $\mathrm{Cu} / \mathrm{Zn}$-SOD activity was defined as the amount of SOD required to produce $50 \%$ inhibition of the rate of nitrite production at $37^{\circ} \mathrm{C}$ in $1 \mathrm{~min}$. Hafeman et al.'s dithio-nitro benzene method was used to determine GPX activity [13]. The GPX activity was assayed at $412 \mathrm{~nm}$ using glutathione as a substrate by measuring the glutathione decrease in the enzymatic reaction (except for the effect of the non-enzymatic reaction). One unit of GPX activity was defined as the amount of enzyme depleting $1 \mu \mathrm{mol}$ of glutathione at $37^{\circ} \mathrm{C}$ in $1 \mathrm{~min}$. The activity of T-AOC was measured at $520 \mathrm{~nm}$ by the method of ferric reducing-antioxidant power assay [14]. One unit of T-AOC was defined as the amount that increased the absorbance by 0.01 at $37{ }^{\circ} \mathrm{C}$ in $1 \mathrm{~min}$. Ceruloplasmin activity was determined according to the method of Martinez-Subiela et al. [15]. One unit of ceruloplasmin activity was defined as the amount of ceruloplasmin consuming $1 \mu \mathrm{mol}$ of substrate (o-dianisidine dihydrochloride) at $37^{\circ} \mathrm{C}$ in $1 \mathrm{~min}$. The method of CAT assay is based upon alteration of hydrogen peroxide optical density, depending on enzymatic decomposition of hydrogen peroxide [16]. One unit of 
Table 1 Composition and nutrient level of the diet (as-fed basis)

\begin{tabular}{|c|c|}
\hline Items & Contents \\
\hline \multicolumn{2}{|l|}{ Ingredients, \% } \\
\hline Maize & 40 \\
\hline Broken rice & 15 \\
\hline Fermented soybean meal & 10 \\
\hline Dehulled soybean meal & 6 \\
\hline Spray-dried animal plasma & 5 \\
\hline Whey powder & 7 \\
\hline Fish meal & 4 \\
\hline Sugar & 4.5 \\
\hline Glucose & 3 \\
\hline Soybean oil & 1.5 \\
\hline L-lysine-HCl, 98 \% & 0.3 \\
\hline L-methionine & 0.15 \\
\hline L-threonine & 0.2 \\
\hline L-tryptophan & 0.05 \\
\hline L-leucine & 0.1 \\
\hline L-isoleucine & 0.05 \\
\hline L-valine & 0.05 \\
\hline Salt & 0.3 \\
\hline Limestone & 1.0 \\
\hline $\mathrm{CaHPO}_{4}$ & 0.8 \\
\hline Vitamin mixture $^{a}$ & 0.2 \\
\hline Mineral mixture ${ }^{b}$ & 0.8 \\
\hline Total & 100 \\
\hline \multicolumn{2}{|l|}{ Nutrient level, \% } \\
\hline Crude protein & 20.2 \\
\hline Digestible energy, Mcal/kg & 3.40 \\
\hline Total calcium & 0.85 \\
\hline Total phosphorus & 0.70 \\
\hline Available phosphorus & 0.44 \\
\hline Digestible lysine & 1.45 \\
\hline Digestible methionine + cystine & 0.79 \\
\hline Digestible threonine & 0.81 \\
\hline Digestible tryptophan & 0.23 \\
\hline Digestible isoleucine & 0.74 \\
\hline Digestible leucine & 1.55 \\
\hline Digestible valine & 0.89 \\
\hline \multicolumn{2}{|l|}{ Analyzed nutrient levels } \\
\hline Calcium, \% & 0.85 \\
\hline Total phosphorus, $\%$ & 0.69 \\
\hline $\mathrm{Fe}, \mathrm{mg} / \mathrm{kg}$ & 199.8 \\
\hline
\end{tabular}

Table 1 Composition and nutrient level of the diet (as-fed basis) (Continued)

\begin{tabular}{ll}
\hline $\mathrm{Zn}, \mathrm{mg} / \mathrm{kg}$ & 122.5 \\
$\mathrm{Cu}, \mathrm{mg} / \mathrm{kg}$ & 127.1 \\
$\mathrm{Mn}, \mathrm{mg} / \mathrm{kg}$ & 63.2 \\
\hline
\end{tabular}

${ }^{a}$ The vitamin mixture supplied the following per kg complete diet: Vitamin $A_{\text {, }}$ 9,000 IU; Vitamin $D_{3}, 3,000$ IU; Vitamin E, 30 IU; Vitamin $\mathrm{K}_{3}, 3$ mg; Vitamin $\mathrm{B}_{1}$, $3 \mathrm{mg}$; Vitamin $B_{2}, 8 \mathrm{mg}$; Vitamin $B_{6}, 5$ mg; Vitamin $B_{12}, 0.04 \mathrm{mg}$; biotin, $0.3 \mathrm{mg}$; pantothenic acid, $20 \mathrm{mg}$; niacin, $45 \mathrm{mg}$; folic acid, $2 \mathrm{mg}$; choline chloride, $450 \mathrm{mg}$

${ }^{\mathrm{b}}$ The mineral mixture supplied the following per kg complete diet: Fe (from ferrous sulfate), $110 \mathrm{mg}$; Cu (from copper sulfate), $120 \mathrm{mg} ; \mathrm{Zn}$ (from zinc sulfate), $100 \mathrm{mg}$; Mn (from manganese sulfate), $50 \mathrm{mg}$; ( (from calcium iodate), $0.9 \mathrm{mg}$; Se (from manganese sulfate), $0.3 \mathrm{mg}$

CAT activity was defined as the amount of CAT consuming $1 \mu \mathrm{mol}$ hydrogen peroxide at $405 \mathrm{~nm}$ for $1 \mathrm{~s}$. The concentration of MDA was measured according to the thiobarbituric acid reactive substance (TBARS) method [17]. Content of protein carbonyl was determined by derivatisation using dinitrophenylhydrazine as reported previously [18].

\section{$\mathrm{Cu} / \mathrm{Zn}$-SOD protein analysis}

The level of $\mathrm{Cu} / \mathrm{Zn}$-SOD protein in the liver were determined using an enzyme linked immunosorbent assay (ELISA) kit (pig-specific, No. 026002, Shanghai Enzyme linked Biotechnology Co., Ltd., Shanghai, China) according to the manufacturer's instruction. The samples were assayed in triplicate. The ELISA results were obtained by a microplate reader at the light length of $450 \mathrm{~nm}$. Hepatic $\mathrm{Cu} / \mathrm{Zn}$-SOD protein was expressed as picogram per milligram $(\mathrm{pg} / \mathrm{mg})$ of total protein. In addition, the activity of $\mathrm{Cu} / \mathrm{Zn}$-SOD was normalised against $\mathrm{Cu} / \mathrm{Zn}$-SOD protein level in each sample for inter-sample comparison.

\section{Trace mineral determination}

The levels of $\mathrm{Se}, \mathrm{Zn}, \mathrm{Fe}, \mathrm{Mn}$, and $\mathrm{Cu}$ were analysed by inductively coupled plasma mass spectrometry (ICP-MS) using an Optimal 2100DV instrument (Perkin-ElmerSciex, Norwalk, NY, USA) equipped with a standard spray chamber (Ryoton) and a cross-flow nebuliser. Briefly, $2 \mathrm{ml}$ of plasma or $1 \mathrm{~g}$ of a liver sample were firstly dissolved in an appropriate amount of $65 \%$ nitric acid and perchloric acid $(3: 1, v / v)$ and then digested on a heating block, after which they were diluted with ultra-pure water to a final volume of $25 \mathrm{~mL}$. Blanks and standard solutions were prepared. After that, samples were analyzed immediately.

\section{Total RNA isolation and mRNA quantification}

Messenger RNA abundance was determined according to method described by Zhang et al. [5]. RNA was isolated using Trizol Reagent (TaKaRa Biotechnology, Dalian, Liaoning, China) from snap-frozen liver sample using the manufacturer's protocol. RNA integrity was checked on $1 \%$ agarose gel with ethidium bromide staining. The RNA 
concentration and purity were determined from OD260/ 280 readings (ratio $>1.8$ ) using a NanoDrop ND-1000 UV spectrophotometer (NanoDrop Technologies, Wilmington, DE, USA). After determining the RNA concentration, $1 \mu \mathrm{g}$ of total RNA was reverse-transcribed into cDNA using PrimeScript $^{\text {tax }}$ RT Reagent Kit (TaKaRa Biotechnology, Dalian, Liaoning, China) according to the manufacturer's guidelines. Real-time PCR was performed on an ABI StepOnePlus $^{\text {tx }}$ Real-Time PCR System (Applied Biosystems, Grand Island, NY, USA) according to the manufacturer's instructions. The primers were designed using the Primer-Blast (http://www.ncbi.nlm.nih.gov). The primer sequences for the target and reference genes (copperand zinc-containing superoxide dismutase $(\mathrm{Cu} / \mathrm{Zn}$-SOD), manganese-containing superoxide dismutase $(\mathrm{Mn} n-S O D)$, glutathione peroxidase 1 (GPX1), thioredoxin (TXN), thioredoxin 2 (TXN2) and $\beta$-actin) are given in Table 2. Briefly, the reaction mixture was prepared using $2 \mu \mathrm{L}$ of cDNA $(50 \mu \mathrm{g} / \mathrm{mL}), 0.4 \mu \mathrm{L}$ of forward primer $(20 \mu \mathrm{mol} / \mathrm{L})$, $0.4 \mu \mathrm{L}$ of reverse primer $(20 \mu \mathrm{mol} / \mathrm{L}), 10 \mu \mathrm{L}$ of SYBR Premix Ex Taq ${ }^{\text {Tw }}$ (TaKaRa Biotechnology, Dalian, Liaoning, China), 0.4 $\mu \mathrm{L}$ of ROX Reference Dye (TaKaRa Biotechnology, Dalian, Liaoning, China) and $6.8 \mu \mathrm{L}$ of doubledistilled water. Each sample was tested in duplicate. RTqPCR consisted of a pre-run at $95^{\circ} \mathrm{C}$ for $30 \mathrm{~s}$ and 40 cycles of denaturation at $95{ }^{\circ} \mathrm{C}$ for $5 \mathrm{~s}$, followed by a $60{ }^{\circ} \mathrm{C}$ annealing step for $30 \mathrm{~s}$. The conditions of the melting curve analysis were as follows: one cycle of denaturation at $95{ }^{\circ} \mathrm{C}$ for $10 \mathrm{~s}$, followed by an increase in temperature from $65{ }^{\circ} \mathrm{C}$ to $95{ }^{\circ} \mathrm{C}$ at a rate of $0.5{ }^{\circ} \mathrm{C} / \mathrm{s}$. The relative levels of mRNA expression were calculated using the $2_{T}^{-\Delta \Delta C}$ method [19], in which the $\beta$-actin gene was amplified as an internal standard.

\section{Statistical analysis}

Data were analyzed by independent-samples $\mathrm{T}$ tests using the SPSS statistical software (Ver.16.0 for windows, SPSS Inc., Chicago, IL, USA). The differences were considered to be significant at $P<0.05$. $P$ values between 0.05 and 0.10 were considered as a trend. All data are presented as group means and standard error.

\section{Results}

\section{Growth performance}

Compared with NBW group (Table 3), IUGR piglets exhibited significantly decreased body weight at both weaning and sampling $(P<0.001)$. The similar effect was also observed for ADG $(P<0.001)$, ADFI $(P=0.003)$ and FE $(P<0.001)$ in IUGR piglets during the first two weeks post-weaning.

\section{Antioxidant capacity}

IUGR piglets had significantly lower plasma T-AOC $(P=$ $0.019)$, T-SOD $(P=0.023)$ and $C P(P=0.044)$ activities, whereas increased MDA $(P=0.040)$ and protein carbonyl $(P=0.010)$ contents than those of NBW piglets (Table 4$)$. IUGR significantly decreased the activities of T-SOD $(P=$ $0.005), \mathrm{Cu} / \mathrm{Zn}-\mathrm{SOD}(P=0.002)$, and CAT $(P=0.049)$ in the liver of piglets compared with NBW piglets. A tendency towards a decreased protein expression of $\mathrm{Cu} /$ $\mathrm{Zn}$-SOD $(P=0.053)$ was observed in the liver of IUGR piglets. IUGR decreased the $\mathrm{Cu} / \mathrm{Zn}$-SOD activity $(P=$ 0.023 ) per unit of $\mathrm{Cu} / \mathrm{Zn}$-SOD protein in the liver of piglets when compared with NBW piglets. IUGR tended to decrease hepatic T-AOC activity $(P=0.085)$ in piglets. There was no significant difference in GPX activity among the groups $(P>0.10)$.

\section{Redox-active trace mineral concentration}

As indicated in Table 5, compared with NBW piglets, IUGR resulted in an obviously decreased $\mathrm{Cu}(P=0.001)$ concentration in the plasma of piglets. Similarly, a tendency towards a decreased level of plasma $\mathrm{Fe}(P=0.079)$ was also observed in IUGR piglets. However, IUGR piglets showed a tendency for increased Se concentration in plasma $(P=0.084)$. In addition, IUGR significantly decreased the concentrations of $\mathrm{Zn}(P=0.048), \mathrm{Fe}(P=$ $0.002)$ and $\mathrm{Cu}(P=0.014)$ in the liver of piglets. No obvious difference was found for the concentration of Mn between the groups $(P>0.10)$.

\section{Gene expression}

The expression levels of genes related to hepatic redox status are summarised in Table 6. IUGR piglets had a

Table 2 Sequences for real-time PCR primers

\begin{tabular}{llllr}
\hline Genes $^{\text {a }}$ & GenBank ID & Primer sequence $\left(5^{\prime} \rightarrow 3^{\prime}\right)$, sense/antisense & Length, bp & Amplification efficiency \\
\hline CU/Zn-SOD & NM_001190422.1 & CATTCCATCATTGGCGCAC/TACACCACAGGCCAAACGA & 118 & 1.01 \\
Mn-SOD & NM_214127.2 & CAAGAAGGGGCACCACGT/CTCAGGGGACGCAAGAACTG & 70 & 1.00 \\
GPX1 & NM_214201.1 & CCTCAAGTACGTCCGACCAG/GTGAGCATTGCGCCATTCA & 85 & 0.98 \\
TXN & NM_214313.2 & CTGCCAAGATGGTGAAGCAG/CGTGGCTGAGAAATCGACCA & 98 & 1.00 \\
TXN2 & NM_001243705.1 & GACGACAGAAGTGCCCTTGA/CTGAGCCATCTCCCAGCAAC & 78 & 1.03 \\
$\beta$-actin & DQ178122 & TCTGGCACCACACCTTCT/TGATCTGGGTCATCTTCTCAC & 114 & 0.99 \\
\hline
\end{tabular}

${ }^{a} \mathrm{Cu} / \mathrm{Zn}$-SOD copper- and zinc-containing superoxide dismutase, $\mathrm{Mn}-\mathrm{SOD}$ manganese-containing superoxide dismutase, GPX1 glutathione peroxidase 1, TXN thioredoxin, TXN2 thioredoxin 2 
Table 3 Effect of intra-uterine growth retardation on growth performance of weaned piglets

\begin{tabular}{llll}
\hline Items $^{\mathrm{a}}$ & IUGR & NBW & $P$ values \\
\hline BW, kg & & & \\
At weaning & $5.31 \pm 0.08$ & $7.05 \pm 0.08$ & $<0.001$ \\
At sampling & $7.34 \pm 0.23$ & $10.70 \pm 0.26$ & $<0.001$ \\
ADG, g/d & $144.73 \pm 12.82$ & $260.51 \pm 13.44$ & $<0.001$ \\
ADFl, g/d & $256.94 \pm 25.80$ & $382.62 \pm 20.00$ & 0.003 \\
FE $^{\text {b }, ~ g / g ~}$ & $0.57 \pm 0.01$ & $0.68 \pm 0.01$ & $<0.001$ \\
\hline
\end{tabular}

a IUGR intra-uterine growth retardation group, NBW normal birth weight group, $A D G$ average daily gain, $A D F I$ average daily feed intake, $F E$ feed efficiency

${ }^{\mathrm{b}} \mathrm{FE}$ was calculated by dividing the ADG by its ADFI

lower mRNA expression of $\mathrm{Cu} / \mathrm{Zn}$-SOD compared with NBW piglets. However, no alterations were observed in the mRNA abundances of $M n-S O D, G P X 1, T X N$ and TXN2 among the groups $(P>0.10)$.

\section{Discussion}

Several studies have demonstrated that IUGR piglets exhibited poor growth performance compared with their heavier counterparts during the post-weaning period $[3,5,20,21]$, and these findings are basically in agreement with the results of the present study in which IUGR piglets had decreased ADG, ADFI, and FE during the first two weeks post-weaning. The factors, such as inadequate nutrient intake, digestive shortcomings, compromised intermediate metabolism or hormonal imbalances, contribute to the poor growth performance of
IUGR offspring [3-5, 20, 21]. However, few studies paid attention on the roles of antioxidant capacity and redoxactive trace minerals exerted in this process.

Oxidative stress occurs when there is an imbalance between production of free radicals and reactive metabolites, so-called reactive oxygen species (ROS), and their elimination by protective mechanisms, referred to as antioxidants [22]. Oxidative damage is believed to play a major role in the pathogenesis of several serious conditions in IUGR infants and to increase the risk of metabolic syndrome in adulthood [23-25]. At the cellular level, the concentrations of ROS (such as superoxide anions, hydrogen peroxide and hydroxyl radicals) exceeding the antioxidant protection levels can cause widespread damage to DNA, proteins and endogenous lipids [26]. To date, descriptions of changes of the redox status during the pigs' lifetime are rather fragmentary [27, 28]. In the present study, increased MDA and protein carbonyl accumulation were observed in fully weaned IUGR piglets, which are similar to the results of Liu et al. [29] who found higher concentrations of MDA and protein carbonyl in the liver of IUGR piglets, which might be associated with the decreased Mn-SOD activity. Superoxide dismutase can reduce the radical superoxide to form hydrogen peroxide and oxygen [30]. The SOD family includes three different enzymes: cytosolic $\mathrm{Cu} / \mathrm{Zn}-\mathrm{SOD}$, mitochondrial Mn-SOD and extracellular SOD [31]. Subsequently, GPX or CAT removes hydrogen peroxide by oxidizing reduced glutathione to oxidized glutathione [32]. In addition, vitamins,

Table 4 Effect of intra-uterine growth retardation on redox status of weaned piglets

\begin{tabular}{llll}
\hline Items $^{\mathrm{a}}$ & IUGR & NBW & $P$ values \\
\hline Plasma & & & \\
T-AOC, U/mL & $3.80 \pm 0.37$ & $5.06 \pm 0.23$ & $117.39 \pm 6.04$ \\
T-SOD, U/mL & $97.92 \pm 3.09$ & $243.86 \pm 7.97$ & 0.023 \\
GPX, U/mL & $246.97 \pm 9.48$ & $148.68 \pm 8.86$ & 0.807 \\
CP, U/L & $124.72 \pm 5.47$ & $1.89 \pm 0.15$ & 0.044 \\
MDA, nmol/mL & $3.03 \pm 0.42$ & $0.25 \pm 0.01$ & 0.040 \\
Protein carbonyl, nmol/mL & $0.32 \pm 0.02$ & & 0.010 \\
Liver & & $5.45 \pm 0.50$ & 0.085 \\
T-AOC, U/mg protein & $4.38 \pm 0.26$ & $86.62 \pm 4.37$ & 0.005 \\
T-SOD, U/mg protein & $65.99 \pm 3.63$ & $63.01 \pm 3.29$ & 0.002 \\
Cu/Zn-SOD, U/mg protein & $45.67 \pm 2.76$ & $142.49 \pm 10.28$ & 0.163 \\
GPX, U/mg protein & $124.05 \pm 6.64$ & $71.27 \pm 6.58$ & 0.049 \\
CAT, U/mg protein & $57.08 \pm 5.47$ & $0.72 \pm 0.09$ & 0.200 \\
MDA, nmol/mg protein & $0.91 \pm 0.11$ & $3.29 \pm 0.61$ & 0.300 \\
Protein carbonyl, nmol/mg protein & $5.02 \pm 1.46$ & $31.81 \pm 1.05$ & 0.053 \\
Cu/Zn-SOD, pg/mg protein & $28.08 \pm 1.34$ & $17.48 \pm 0.94$ & 0.023 \\
Cu/Zn-SOD, U/pg Cu/Zn-SOD protein & $14.00 \pm 0.90$ & \\
\hline
\end{tabular}

a IUGR intra-uterine growth retardation group, NBW normal birth weight group, $T$-AOC total antioxidant capacity, $T$-SOD total superoxide dismutase, $\mathrm{CU} / \mathrm{Zn}$-SOD copper- and zinc-containing superoxide dismutase, GPX glutathione peroxidise, CP ceruloplasmin, MDA malondialdehyde, CAT catalase 
Table 5 Effect of intra-uterine growth retardation on the concentrations of redox-active trace minerals of weaned piglets

\begin{tabular}{clll}
\hline Items $^{a}$ & IUGR & NBW & $P$ values \\
\hline Plasma, mg/L & & & \\
$\mathrm{Se}$ & $0.37 \pm 0.01$ & $0.31 \pm 0.03$ & 0.084 \\
$\mathrm{Zn}$ & $0.33 \pm 0.02$ & $0.36 \pm 0.03$ & 0.342 \\
$\mathrm{Fe}$ & $6.92 \pm 0.63$ & $8.51 \pm 0.51$ & 0.079 \\
$\mathrm{Mn}$ & $0.29 \pm 0.01$ & $0.32 \pm 0.01$ & 0.102 \\
$\mathrm{Cu}$ & $1.68 \pm 0.07$ & $2.08 \pm 0.05$ & 0.001 \\
Liver, mg/kg wet weight & & \\
$\mathrm{Se}$ & $0.46 \pm 0.06$ & $0.66 \pm 0.13$ & 0.196 \\
$\mathrm{Zn}$ & $58.64 \pm 4.27$ & $73.17 \pm 4.85$ & 0.048 \\
$\mathrm{Fe}$ & $102.96 \pm 7.51$ & $158.23 \pm 11.13$ & 0.002 \\
$\mathrm{Mn}$ & $3.04 \pm 0.16$ & $3.24 \pm 0.20$ & 0.453 \\
$\mathrm{Cu}$ & $10.75 \pm 0.65$ & $14.41 \pm 1.06$ & 0.014 \\
\hline
\end{tabular}

a IUGR intra-uterine growth retardation group, NBW normal birth weight group, Se selenium, $\mathrm{Zn}$ zinc, $\mathrm{Fe}$ iron, $\mathrm{Mn}$ manganese, $\mathrm{Cu}$ copper

biological antioxidants, CP and uric acid also play important roles in scavenging the oxygen free radicals. Here, IUGR-induced oxidative injury was found to reduce the T-AOC activity in both plasma and liver, which is in accordance with the findings of Michiels et al. [21]. The T-AOC reflects the levels of non-enzymatic antioxidant defense system and antioxidant enzyme. In contrast to the results of Michiels et al. [21], we failed to observe a decrease in GPX activity in the plasma of IUGR piglets. However, a significantly depressed T-SOD and $\mathrm{Cu} / \mathrm{Zn}$-SOD activities were found in IUGR piglets. These observations pointed to a lower antioxidant capacity of fully weaned IUGR pigs upon ROS and oxidants when oxidative stress occurred. Moreover, the mRNA abundance of $\mathrm{Cu} / \mathrm{Zn}$-SOD was down-regulated by IUGR in the liver of piglets, which may provide an explanation for the decreased protein expression of hepatic $\mathrm{Cu} / \mathrm{Zn}-\mathrm{SOD}$.

Using the state-of-the-art ICP-MS technique, a recent study found strong associations between ionomic profiles and metabolic abnormalities [33]. Likewise, the redox status is closely related to the concentrations of

Table 6 Effect of intra-uterine growth retardation on hepatic gene expression related to redox status of weaned piglets

\begin{tabular}{lllc} 
Items $^{\mathrm{a}}$ & IUGR & NBW & $P$ values \\
\hline CU/Zn-SOD & $0.84 \pm 0.03$ & $1.23 \pm 0.14$ & 0.021 \\
Mn-SOD & $1.02 \pm 0.11$ & $1.02 \pm 0.05$ & 0.973 \\
GPX1 & $0.94 \pm 0.18$ & $1.18 \pm 0.12$ & 0.290 \\
TXN & $0.95 \pm 0.06$ & $1.07 \pm 0.07$ & 0.233 \\
TXN2 & $0.96 \pm 0.07$ & $1.11 \pm 0.15$ & 0.417
\end{tabular}

a IUGR intra-uterine growth retardation group, NBW normal birth weight group, $C U / Z n-S O D$ copper- and zinc-containing superoxide dismutase, $M n-S O D$ manganese-containing superoxide dismutase, GPX1 glutathione peroxidase 1, TXN thioredoxin, TXN2 thioredoxin 2 redox-active trace minerals in fully weaned IUGR piglets. In the present study, we found that IUGR piglets had lower concentrations of $\mathrm{Fe}$ in both plasma and liver, coupled with a decrease in hepatic CAT activity. Although the role of Fe in heme for oxygen transport is well known, its role for redox status as a component of peroxidase and CAT should not be overlooked. Schultze and Kuiken reported that Fe deficiency could lead to a decreased hepatic CAT activity [34]. Macdougall also found that the activities of GPX and CAT increased in iron-deficient children following Fe treatment [35].

Copper serves many roles in the body and often it acts as an enzyme activator. Notably, $\mathrm{Cu}$ is known to be important in changing the valence of $\mathrm{Fe}$ for binding to transferrin and ferritin [36]. The lower Fe accumulation in the IUGR piglets may also partially result from the simultaneously decreased $\mathrm{Cu}$ concentration. Ceruloplasmin as an acute-phase protein binds 90 to $95 \%$ of the $\mathrm{Cu}$ in the blood and is also responsible for the transport of $\mathrm{Cu}$ [37]. Hill et al. reported that neonatal pigs with $\mathrm{Cu}$ deficiency showed no serum $\mathrm{CP}$ activity [38]. Therefore, there was a positive relation between the decreased $\mathrm{Cu}$ content and the lower CP activity in IUGR piglets. Ceruloplasmin is not just involved in the transport of $\mathrm{Cu}$, but it is an antioxidant enzyme. The decreased plasma CP activity also confirmed the poor antioxidant capacity of fully weaned IUGR piglets.

Additionally, previous study found a lower concentration of both $\mathrm{Zn}$ and $\mathrm{Cu}$ in IUGR placentas [39]. Zinc has a vital role in a wide range of biological functions through its participation as a constituent of more than 100 metalloenzyme systems. The free-radical scavenging mechanisms may be impaired in the case of $\mathrm{Zn}$ deficiency. The activity of SOD is not only activated by the expression of SOD-related genes but also mediated by other factors, such as $\mathrm{Zn}$ and $\mathrm{Cu}$ levels [40]. Zinc as a component of $\mathrm{Cu} / \mathrm{Zn}-\mathrm{SOD}$ is closely inter-related to antioxidant functions [40]. Besides, decrease of both $\mathrm{Zn}$ and $\mathrm{Cu}$ concentrations may be caused by the increase of Se content in the plasma of IUGR piglets, as Se appears to mimic the behavior of $\mathrm{Zn}$ and is opposite to that of $\mathrm{Cu}$ [41]. Their higher Se concentration might play a positive role in maintaining Se-dependent GPX activity at the level comparable with GPX activity in NBW piglets.

\section{Conclusions}

The present study indicates that the metabolism of redox-active trace minerals such as $\mathrm{Fe}, \mathrm{Cu}$, and $\mathrm{Zn}$ in the IUGR piglets may be inferior, which most likely due to simultaneously reduced feed intake. The results may offer a possible explanation for the impaired antioxidant system in the IUGR piglets. This study may help to guide nutrition interventions for IUGR offspring to alleviate oxidative damage during the early period after weaning. 


\section{Abbreviations}

CAT: catalase; CP: ceruloplasmin; Cu: copper; Cu/Zn-SOD: copper- and zinc-containing superoxide dismutase; Fe: iron; GPX: glutathione peroxidise; GPX1: glutathione peroxidase 1; ICP-MS: inductively coupled plasma mass spectrometry; IUGR: intra-uterine growth retardation group; MDA: malondialdehyde; Mn: manganese; Mn-SOD: manganese-containing superoxide dismutase; NBW: normal body weight group; ROS: reactive oxygen species; Se: selenium; SOD: superoxide dismutase; T-AOC: total antioxidant capacity; TXN: thioredoxin; TXN2: thioredoxin 2; Zn: zinc.

\section{Competing interests}

The authors declare that they have no competing interests.

\section{Authors' contributions}

The contributions of the authors are as follows: $\mathrm{HZ}$ and $\mathrm{YL}$ participated in study design and animal experiment. $\mathrm{HZ}$ and $\mathrm{YL}$ conducted the research and data interpretation. $\mathrm{HZ}$ discussed the results and wrote the paper. $\mathrm{HZ}$ gave the original idea and TW was in charge of the whole trial. All authors read and approved the final manuscript.

\section{Acknowledgements}

The authors thank their laboratory colleagues for their assistance. This study was supported by the National Natural Science Foundation of China (31272454).

Received: 23 June 2015 Accepted: 29 October 2015

Published online: 19 November 2015

\section{References}

1. Wu G, Bazer FW, Wallace JM, Spencer TE. Board-invited review: intrauterine growth retardation: implications for the animal sciences. J Anim Sci. 2006:84:2316-37.

2. Widdowson EM, Crabb DE, Milner RD. Cellular development of some human organs before birth. Arch Dis Child. 1972;47:652-5.

3. Hales CN, Barker DJ. The thrifty phenotype hypothesis. Br Med Bull. 2001;60:5-20.

4. Wang JJ, Chen LX, Li DF, Yin YL, Wang XQ, Li P, et al. Intrauterine growth restriction affects the proteomes of the small intestine, liver, and skeletal muscle in newborn pigs. J Nutr. 2008;138:60-6.

5. Zhang H, Chen YP, Li Y, Yang L, Wang JJ, Wang T. Medium-chain TAG attenuate hepatic oxidative damage in intra-uterine growth-retarded weanling piglets by improving the metabolic efficiency of the glutathione redox cycle. Br J Nutr. 2014;112:876-85.

6. Merrifield CA, Lewis M, Claus SP, Beckonert OP, Dumas ME, Duncker S, et al. A metabolic system-wide characterization of the pig: a model for human physiology. Mol Biosyst. 2011;7:2577-88.

7. Liu C, Lin G, Wang XQ, Wang TJ, Wu GY, Li DF, et al. Intrauterine growth restriction alters the hepatic proteome in fetal pigs. J Nutr Biochem. 2013:24:954-9.

8. Lukaski HC. Vitamin and mineral status: effects on physical performance. Nutrition. 2004:20:632-44

9. Richards JD, Zhao JM, Harrell RJ, Atwell CA, Dibner JJ. Trace Mineral Nutrition in Poultry and Swine. Asian-Austral J Anim. 2010;23:1527-34

10. Wang T, Huo YJ, Shi F, Xu RJ, Hutz RJ. Effects of intrauterine growth retardation on development of the gastrointestinal tract in neonatal pigs. Biol Neonate. 2005:88:66-72.

11. National Research Council. Nutrient requirements of swine. 11th ed. Washington, DC: National Academic Press; 2012

12. Ōyanagui $Y$. Reevaluation of assay methods and establishment of kit for superoxide dismutase activity. Anal Biochem. 1984;142:290-6.

13. Hafeman DG, Sunde RA, Hoekstra WG. Effect of dietary selenium on erythrocyte and liver glutathione eroxidise in the rat. J Nutr. 1974;104:580-7.

14. Benzie IF, Strain JJ. The ferric reducing ability of plasma (FRAP) as a measure of "antioxidant power": the FRAP assay. Anal Biochem. 1996;239:70-6.

15. Martinez-Subiela S, Tecles F, Ceron JJ. Comparison of two automated spectrophotometric methods for ceruloplasmin measurement in pigs. Res Vet Sci. 2007;83:12-9.

16. Wang D, Wang L, Zhu F, Zhu J, Chen X, Zou L, et al. In vitro and in vivo studies on the antioxidant activities of the aqueous extracts of Douchi (a traditional Chinese salt-fermented soybean food). Food Chem. 2008;107:1421-8.

17. Placer ZA, Cushman LL, Johnson BC. Estimation of product of lipid peroxidation (malonyl dialdehyde) in biochemical systems. Anal Biochem. 1966;16:359-64.
18. Ganhao R, Morcuende D, Estevez M. Protein oxidation in emulsified cooked burger patties with added fruit extracts: Influence on colour and texture deterioration during chill storage. Meat Sci. 2010;85:402-9.

19. Livak KJ, Schmittgen TD. Analysis of relative gene expression data using real-time quantitative PCR and the 2(-Delta Delta C(T)) Method. Methods. 2001;25:402-8.

20. Bruininx EM, van der Peet-Schwering CM, Schrama JW, Vereijken PF, Vesseur PC, Everts $\mathrm{H}$, et al. Individually measured feed intake characteristics and growth performance of group-housed weanling pigs: effects of sex, initial body weight, and body weight distribution within groups. J Anim Sci. 2001;79:301-8

21. Michiels J, De Vos M, Missotten J, Ovyn A, De Smet S, Van Ginneken C. Maturation of digestive function is retarded and plasma antioxidant capacity lowered in fully weaned low birth weight piglets. Br J Nutr. 2013;109:65-75.

22. Durackova Z. Some current insights into oxidative stress. Physiol Res. 2010;59:459-69.

23. Weinberger B, Anwar M, Henien S, Sosnovsky A, Hiatt M, Jochnowitz N, et al. Association of lipid peroxidation with antenatal betamethasone and oxygen radical disorders in preterm infants. Neonatology. 2004;85:121-7.

24. Friel JK, Bill DJ, Cockell KA, Aaron C, Rasheda R, Davies SS, et al. Evidence of oxidative stress in relation to feeding type during early life in premature infants. Pediatr Res. 2011:69:160-4.

25. Aroor AR, Mandavia C, Ren J, Sowers JR, Pulakat L. Mitochondria and oxidative stress in the cardiorenal metabolic syndrome. Cardiorenal Medicine. 2012;2:87-109.

26. Yu BP. Cellular defenses against damage from reactive oxygen species. Physiol Rev. 1994;74:139-62.

27. Petrovic V, Novotny J, Hisira V, Link R, Leng L, Kovác G. The impact of suckling and post-weaning period on blood chemistry of piglets. Acta Vet BRNO. 2009;78:365-71.

28. Sauerwein $\mathrm{H}$, Schmitz S, Hiss S. The acute phase protein haptoglobin and its relation to oxidative status in piglets undergoing weaning-induced stress. Redox Rep. 2005:10:295-302.

29. Liu J, Yao Y, Yu B, Mao X, Huang Z, Chen D. Effect of folic acid supplementation on hepatic antioxidant function and mitochondrial-related gene expression in weanling intrauterine growth retarded piglets. Livest Sci. 2012;146:123-32.

30. Mccord JM. Superoxide, superoxide dismutase and oxygen toxicity. Rev Biochem Toxicol. 1979;1:109-24.

31. Zelko IN, Mariani TJ, Folz RJ. Superoxide dismutase multigenefamily: a comparison of the CuZn-SOD (SOD1), Mn-SOD (SOD2), and EC-SOD (SOD3) gene structures, evolution, and expression. Free Radic Biol Med. 2002;33:337-49.

32. Cecarini V, Gee J, Fioretti E, Amici M, Angeletti M, Eleuteri AM, et al. Protein oxidation and cellular homeostasis: Emphasis on metabolism. Biochim Biophys Acta. 2007;1773:93-104

33. Sun $L, Y u Y$, Huang $T$, An $P, Y u$ D, Yu Z, et al. Associations between ionomic profile and metabolic abnormalities in human population. Plos One. 2012;7:e38845

34. Schultze MO, Kuiken KA. The effect of deficiencies in copper and iron on the catalase activity of rat tissues. J Biol Chem. 1941;137:727-34.

35. Macdougall LG. Red cell metabolism in iron deficiency anemia. 3. the relationship between glutathione peroxidase, catalase, serum vitamin $\mathrm{E}$, and susceptibility of iron-deficient red cells to oxidative hemolysis. J Pediatr. 1972;80:775-82

36. Baker DH. Bioavailability of Minerals and Vitamins. In: Lewis AJ, Southern LL, editors. Swine Nutrition. Boca Raton: CRC Press LLC; 2001. p. 368-9.

37. Sang QA. Specific proteolysis of ceruloplasmin by leukocyte elastase. Biochem Mol Biol Int 1995:37:573-81.

38. Hill GM, Ku PK, Miller ER, Ullrey DE, Losty TA, O'Dell BL. A copper deficiency in neonatal pigs induced by a high zinc maternal diet. J Nutr. 1983;113:867-939.

39. Zadrozn M, Gawlik M, Nowak B, Marcinek A, Mrowiec H, Walas S, et al. Antioxidants activities and concentration of selenium, zinc and copper in preterm and IUGR human placentas. J Trace Elem Med Bio. 2009;23:144-8.

40. Chakraborty I, Kunti S, Bandyopadhyay M, Dasgupta A, Chattopadhyay GD, Chakraborty S. Evaluation of serum zinc level and plasma SOD activity in senile cataract patients under oxidative stress. Indian J Clin Biochem. 2007;22:109-13.

41. Kantola M, Purkunen R, Kroger P, Tooming A, Juravskaja J, Pasanen M, et al. Accumulation of cadmium, zinc and copper in maternal blood and developmental placental tissue: differences between Finland, Estonia, and St. Petersburg. Environ Res. 2000;A83:54-66. 